\title{
Pengaruh Model Pembelajaran Scramble Bermuatan Literasi Sains terhadap Kompetensi Belajar Peserta Didik pada Materi Sistem Pernapasan Manusia di SMPN 13 Padang
}

\author{
Kresy Monery Sitompul $^{1)}$, Siska Alicia Farma ${ }^{2)}$, Syamsurizal ${ }^{3)}$ \\ ${ }^{1), 2), 3)}$ Jurusan Biologi FMIPA Universitas Negeri Padang, Padang, Indonesia
}

Pengiriman: 22 November 2019; Diterima: 26 Nopember 2019; Publikasi: Nopember 2019

\begin{abstract}
This research is based on the problems that exist in SMPN 13 Padang, namely the learning model that is less varied, students learning abilities are still low, teacher-centered learning. The effort that can be done to apply the scramble learning model with science literacy in the human respiratory system at SMPN 13. The purpose of this research was to determine the effect of applying the scramble learning model with scientific literacy on the learning competencies of grade VIII students of SMP 13 Padang. This research was an experimental research with a randomized control group posttest only design. The study population was grade VIII students of SMP 13 Padang in the 2018/2019 academic year which spread to eight classes. The research sample was taken using purposive sampling. The results were selected class VIII.3 as the experimental class and class VIII.2 as the control class. The hypothesis in this study was tested using the t-test. The results of the study using the t-test can be concluded that the competency of students knowledge about the value of tcount 2.83> ttable 1.67, the competency attitudes of tcount 5.77> ttable 1.67, and competency skills of tcount 1.91> ttable 1.67. This point that the alternative hypothesis is accepted. So, it can be concluded that the application of the scramble learning model with scientific literacy can improve the competency of knowledge, attitudes, and skills of grade VIII students of SMP 13 Padang.
\end{abstract}

Keywords: Scramble, Science Literacy, Learning Competencies

\begin{abstract}
ABSTRAK: Penelitian ini didasarkan pada permasalahan yang ada di SMPN 13 Padang, yaitu model pembelajaran yang kurang beragam, kemampuan belajar siswa masih rendah, pembelajaran yang berpusat pada guru. Perlu upaya untuk menerapkan model pembelajaran dengan orientasi literasi sains dalam sistem pernapasan manusia di SMPN 13. Tujuan penelitian ini adalah untuk menguji dampak penerapan model pembelajaran dengan literasi sains terhadap kompetensi belajar siswa kelas VIII SMP 13 Padang. Penelitian ini adalah penelitian eksperimental dengan randomized control group posttest only design. Populasi dalam studi ini adalah siswa kelas VIII SMP 13 Padang pada tahun akademik 2018/2019 yang menyebar ke delapan kelas. Sampel penelitian diambil dengan menggunakan purposive sampling. Hasil yang dipilih adalah kelas VIII. 3 sebagai kelas eksperimental dan kelas VIII. 2 sebagai kelas kontrol. Hipotesis dalam studi ini diuji menggunakan t-Test. Hasil penelitian menggunakan t-Test dapat disimpulkan bahwa kompetensi siswa dengan nilai t-hitung 2,83 > t-tabel 1,67, kompetensi sikap dengan t-hitung5,77 > t-table 1,67, dan keterampilan dengan t-hitung 1,91 > t-tabel 1,67. Dengan demikian hipotesis alternative diterima. Sehingga dapat disimpulkan bahwa penerapan model pembelajaran dengan literasi sains dapat meningkatkan kompetensi pengetahuan, sikap, dan keterampilan siswa kelas VIII SMP 13 Padang.
\end{abstract}

Kata Kunci: Model Pembelajaran Scramble, Literasi Sains, Kompetensi

*Penulis Korespondensi:

Alamat surel: Sitompulkrsy@gmail.com 


\section{PENDAHULUAN}

Pembelajaran IPA disekolah hendaknya mengarahkan peserta didik memperoleh pemahaman lebih mendalam terhadap alam sekitar, sehingga menjadi tantangan tersendiri bagi pendidik bidang IPA. Jufri (2013: 162) mengemukakan pendidik IPA dimasa depan harus mampu merancang dan melaksanakan pembelajaran yang berpusat pada aktivitas belajar peserta didik, pembelajaran dengan beragam pilihan dan pembelajaran dengan akuntabilitas tinggi.

Fakta dilapangan yang merupakan hasil wawancara yang dilakukan terhadap salah satu guru IPA kelas VIII SMPN 13 Padang pada tanggal 4 September 2018 yaitu guru umumnya menggunakan model konvensional atau model yang lebih berfokus ke guru (teacher-centered)dan ada beberapa metode yang sering digunakan salah satunya metode ceramah. Sehingga guru hanya menyampaikan IPA sebagai produk dan peserta didik hanya menerima dan menghafal informasi yang disampaikan oleh guru. Akibatnya IPA sebagai produk, sikap dan aplikasi tidak tersentuh dalam pembelajaran dan pengalaman belajar yang diperoleh dikelas tidak utuh serta terjadi kegagalan dalam pencapaian standar kompetensi dan kompetensi dasar.

Berdasarkan hasil observasi terhadap peserta didik dapat dikatakan penggunaan model tersebut masih kurang efektif digunakan dalam pembelajaran, yang mana didapatkan hasil $61 \%$ peserta didik tidak menyukai model yang sering diterapkan guru dan $46 \%$ peserta didik menyatakan kurang memahami materi melalui model tersebut. Hal ini berdampak terhadap rendahnya kompetensi pengetahuan peserta didik yang terlihat dari hasil ujian akhir sekolah IPA semester ganjil tahun ajaran 2017/2018.

Tabel 1. Nilai Rata-Rata Ujian Tengah Semester Peserta Didik Kelas VIII Semester 1 SMPN 13 Padang Tahun Pelajaran 2017/2018.

\begin{tabular}{cccccc}
\hline No & & $\begin{array}{c}\text { Jumlah } \\
\text { siswa }\end{array}$ & \multicolumn{2}{c}{ Ketuntasan } & $\begin{array}{c}\text { Nilai } \\
\text { Rata- } \\
\text { Rata }\end{array}$ \\
\cline { 3 - 6 } & Kelas & & Tuntas & $\begin{array}{c}\text { Tidak } \\
\text { Tuntas }\end{array}$ \\
\hline 1 & & & 3 & 29 & 70.31 \\
2 & VIII.1 & 32 & 0 & 32 & 57.34 \\
3 & VIII.2 & 32 & 0 & 32 & 57.81 \\
4 & VIII.4 & 32 & 0 & 32 & 55.70 \\
5 & VIII.5 & 30 & 0 & 30 & 52.25 \\
6 & VIII.6 & 32 & 0 & 32 & 46.25 \\
7 & VIII.7 & 32 & 0 & 32 & 52.10 \\
8 & VIII.8 & 31 & 0 & 32 & 43.83 \\
\hline \multicolumn{2}{c}{ Jumlah } & 253 & & & \\
\multicolumn{2}{c}{ siswa } & & &
\end{tabular}

Berdasarkan nilai rata-rata diatas dapat terlihat bahwa proses pembelajaran IPA disekolah masih belum efektif sehingga pemasalahan tersebut akan berhubungan dengan literasi sains yang dimiliki peserta didik. PISA (Programme forInternational Students Assessment) mendefenisikan literasi sains (science literacy) pengetahuan dan penggunaannya untuk mengidentifikasi pertanyaan, memperoleh pengetahuan baru, menjelaskan fenomena ilmiah dan menarik kesimpulan berdasarkan bukti-bukti. Hasil riset PISA yang diselenggarakan oleh OECD (Organization for Economic Cooperation and Development) pada tahun 2015, literasi sains yang dimiliki peserta didik Indonesia menduduki peringkat 62 dari 70 negara dengan skor rata-rata 403 sedangkan skor rata-rata PISA yaitu 493 (OECD, 2016: 4). Dari segi keterampilan proses sains sendiri, siswa masih cenderung menunjukkan tingkatan KPS yang rendah (Irawan, B., Putri, 
A.Z., 2019:3). Hasil tersebut menunjukkan bahwa literasi sains yang dimiliki oleh peserta didik indonesia masih rendah.

Rendahnya literasi sains peserta didik di Indonesia didukung dengan tidak banyaknya peserta didik yang menyukai bidang kajian IPA. Menurut Trianto (2012: 154-155) kenyataannya tidak banyak peserta didik yang menyukai bidang kajian IPA, karena dianggap sukar, keterbatasan kemampuan peserta didik, atau karena mereka tak berminat, namun demikian, mereka tetap berharap agar pembelajaran IPAdisekolah dapat disajikan secara menarik, efisien, dan efektif. Harapan tersebut dapat terwujud dengan kemampuan guru dalam memilih model pembelajaran.

Salah satu model pembelajaran yang dapat dicobakan untuk mengatasi masalah tersebut adalah model pembelajaran scramble.Model pembelajaran scramble ini memiliki beberapa kelebihan menurut Huda(2013: 304), yaitu: 1) melatih tanggung jawab anggota kelompok karena setiap anggota memiliki tugas masing-masing, 2) menimbulkan kegembiraan dan membuat peserta didik merasa lebih santai karena model ini memungkinkan peserta didik untuk belajar sambil bermain, 3) model scramble dapat memupuk membangkitkan rasa solidaritas dalam kelompok, 4) materi yang menggunakan model ini akan memiliki kesan tersendiri dan sulit untuk dilupakan dan 5) memunculkan sifat kompetitif karena model ini mendorong peserta didik berlomba lomba untuk maju.

Berdasarkan masalah yang dikemukakan, maka peneliti melakukan penelitian yang berjudul pengaruh model pembelajaranscramblebermuatan
Literasi Sains pada materi sistem pernapasan manusiadi kelas VIII SMP Negeri 13 Padang.

\section{METODE PENELITIAN}

Penelitian ini dilaksanakan pada semester genap Tahun Ajaran 2018/2019. Penelitian ini merupakan penelitian eksperimen semu dengan desain penelitian Randomized Control Group Posttest Only Design. Peneliti menggunakan sekelompok subyek penelitian dari suatu populasi, kemudian dikelompokkan secara random menjadi dua kelas, yaitu kelas eskperimen dan kelas kontrol. Pada kelas eksperimen diberikan perlakuan dengan model pembelajaranscramblebermuatan literasi sains, sedangkan kelas kontrol diberikan perlakuan dengan model pembelajaran konvensional. Selanjutnya diberi posttest pada kedua kelas sampel.

Populasi dalam penelitian ini adalah seluruh kelas VIII di SMPN 13 Padang yang terdaftar pada tahun ajaran 2018/2019 yang meliputi delapan kelas.Sampel penelitian ditentukan dengan menggunakan teknik purposive sampling.Penelitian ini dilaksanakan selama empat pertemuan (10 JP).Instrumen penelitian yang digunakan untuk menilai kompetensi pengetahuan berupa tes akhir (posttest), kompetensi sikap menggunakan lembar observasi sikap dan rubrik penilaian, dan kompetensi keterampilan menggunakan lembar observasi penilaian produk dan rubrik penilaian. Lembar observasi sikap beserta rubrik penilaiannya dikembangkan dari paduan penilaian Direktorat Jenderal Pendidikan Dasar dan Menengah tahun 2017 dan Lembar observasi keterampilan beserta rubrik penilaiannya dikembangkan dari PSMP 2014. Instrumen 
penilaian kompetensi pengetahuan, sikap, dan keterampilan divalidasi oleh guru SMP Negeri 13 Padang.

\section{Menurut Ngalimun (2012:176) Model}

Scramble memiliki sintaks sebagai berikut: a) guru membuat kartu soal sesuai materi ajar, b)guru membuat kartu jawaban yang diacak hurufnya, c) guru menyajikan materi pelajaran, d) guru membagi peserta didik ke dalam beberapa kelompok, e) guru membagikan kartu soal dan membagikan kartu jawaban kepada peserta didik, dan f) peserta didik berkelompok dan saling membantu mencari jawaban yang cocok untuk setiap soal yang mereka kerjakan dan memasangkannya pada kartu soal. Data penelitian ini dianalisis menggunakan uji statistik. Data kompetensi pengetahuan menggunakan uji t yang terlebih dahulu dilakukan uji normalitas dan uji homogenitas.

\section{HASIL DAN PEMBAHASAN}

\section{A. Hasil Penelitian}

Berdasarkan penelitian yang dilakukan di SMPN 13 Padang pada bulan Januari-februari2019 dengan sampel penelitian peserta didik kelas VIII.2 dan VIII.3, diperoleh hasil penelitian untuk kompetensi pengetahuan, sikap dan keterampilan.

\section{Kompetensi pengetahuan}

Hasil penelitian tentang pengaruh model scramble bermuatan literasi sains terhadap kompetensi pengetahuan peserta didik pada materi sistem pernapasan manusia di kelas VIII, dapat dilihat pada Tabel 2.

Tabel 2. Data Kompetensi Pengetahuan Peserta Didik Kelas Sampell.

\begin{tabular}{lllll}
\hline \multirow{2}{*}{ No Parameter } & \multicolumn{2}{c}{ Kelas } & Keterangan \\
\cline { 3 - 5 } & \multicolumn{1}{c}{$\begin{array}{l}\text { Eksperi } \\
\text { men }\end{array}$} & Kontrol & \\
\hline 1 & Rata-rata & 73,25 & 67,13 & $\bar{x}_{1}>\bar{x}_{2}$ \\
2 & Uji & $\mathrm{L}_{0}=0,15$ & $\mathrm{~L}_{0}=0,15$ & Terdistribusi \\
& normalitas & $\mathrm{L}_{\mathrm{t}}=0,16$ & $\mathrm{~L}_{\mathrm{t}}=0,16$ & normal \\
3 & Uji & $\mathrm{F}_{\text {hitung }}=0,74<\mathrm{F}_{\text {tabel }}=$ & $\mathrm{F}_{\text {hitung }}<\mathrm{F}_{\text {tabel }}$ \\
& homogenit & Varians \\
& as & 1,84 & Homogen \\
4 & Uji & & $t_{\text {hitung }} \mathrm{t}_{\text {tabel }}$ \\
& hipotesis & $\mathrm{t}_{\text {hitung }}=2,83>\mathrm{t}_{\text {tabel }}=$ & sehingga \\
& (Uji t) & 1,67 & Hipotesis \\
& & & Diterima \\
\hline
\end{tabular}

\section{Kompetensi sikap}

Hasil penelitian tentang pengaruh model scramble bermuatan literasi sains terhadap kompetensi sikap peserta didik pada materi sistem pernapasan manusia di kelas VIII, dapat dilihat pada Tabel 3.

Tabel 3. Data Kompetensi Sikap Peserta Didik Kelas Sampel

\begin{tabular}{|c|c|c|c|c|}
\hline \multirow[b]{2}{*}{ No } & \multirow[b]{2}{*}{ Parameter } & \multicolumn{2}{|c|}{ Kelas } & \multirow{2}{*}{$\begin{array}{c}\text { Keteranga } \\
\text { n }\end{array}$} \\
\hline & & $\begin{array}{l}\text { Eksperi } \\
\text { men }\end{array}$ & Kontrol & \\
\hline 1 & Rata-rata & 81,31 & 73,28 & $\bar{x}_{1}>\bar{x}_{2}$ \\
\hline 2 & $\begin{array}{l}\text { Uji } \\
\text { normalitas }\end{array}$ & $\begin{array}{l}\mathrm{L}_{0}=0,09 \\
\mathrm{~L}_{\mathrm{t}}=0,16\end{array}$ & $\begin{array}{l}\mathrm{L}_{0}=0,14 \\
\mathrm{~L}_{\mathrm{t}}=0,16\end{array}$ & $\begin{array}{l}\text { Terdistribusi } \\
\text { normal }\end{array}$ \\
\hline 3 & $\begin{array}{l}\text { Uji } \\
\text { homogenit } \\
\text { as }\end{array}$ & \multicolumn{2}{|c|}{$\begin{array}{l}\mathrm{F}_{\text {hitung }}=0,36<\mathrm{F}_{\text {tabel }}= \\
1,84\end{array}$} & $\begin{array}{l}\mathrm{F}_{\text {hitung }}<\mathrm{F}_{\text {tabel }} \\
\text { varians } \\
\text { Homogen }\end{array}$ \\
\hline 4 & $\begin{array}{l}\text { Uji } \\
\text { hipotesis } \\
\text { (Uji t) }\end{array}$ & \multicolumn{2}{|c|}{$\begin{array}{l}t_{\text {hitung }}=5,77>t_{\text {tabel }}= \\
1,67\end{array}$} & $\begin{array}{l}t_{\text {hitung }}>t_{\text {tabel }} \\
\text { sehingga } \\
\text { Hipotesis } \\
\text { Diterima }\end{array}$ \\
\hline
\end{tabular}

\section{Kompetensi keterampilan}

Hasil penelitian tentang pengaruh model scramble bermuatan literasi sains terhadap kompetensi keterampilan peserta didik pada materi sistem pernapasan manusia di kelas VIII, dapat dilihat pada tabel 4. 
Tabel 4. Data Kompetensi Keterampilan Peserta Didik Kelas Sampel

\begin{tabular}{|c|c|c|c|c|}
\hline \multirow[b]{2}{*}{ No } & \multirow[b]{2}{*}{ Parameter } & \multicolumn{2}{|c|}{ Kelas } & \multirow{2}{*}{$\begin{array}{c}\text { Keterang } \\
\text { an }\end{array}$} \\
\hline & & $\begin{array}{l}\text { Eksperi } \\
\text { men }\end{array}$ & Kontrol & \\
\hline 1 & Rata-rata & 83,91 & 79,59 & $\bar{x}_{1}>\bar{x}_{2}$ \\
\hline 2 & $\begin{array}{l}\text { Uji } \\
\text { normalitas }\end{array}$ & $\begin{array}{l}\mathrm{L}_{0}=0,13 \\
\mathrm{~L}_{\mathrm{t}}=0,16\end{array}$ & $\begin{array}{l}\mathrm{L}_{0}=0,14 \\
\mathrm{~L}_{\mathrm{t}}=0,16\end{array}$ & $\begin{array}{l}\text { Terdistribu } \\
\text { si normal }\end{array}$ \\
\hline 3 & $\begin{array}{l}\text { Uji } \\
\text { homogenit } \\
\text { as }\end{array}$ & $\begin{array}{l}F_{\text {hitung }}=1 \text {, } \\
1,84\end{array}$ & $50<\mathrm{F}_{\text {tabel }}=$ & $\begin{array}{l}\mathrm{F}_{\text {hitung }}<\mathrm{F}_{\text {tabel }} \\
\text { varians } \\
\text { Homogen }\end{array}$ \\
\hline 4 & $\begin{array}{l}\text { Uji } \\
\text { hipotesis } \\
\text { (Uji t) }\end{array}$ & $\begin{array}{l}\mathrm{t}_{\text {hitung }}=1,8 \\
1,67\end{array}$ & $7>\mathrm{t}_{\text {tabel }}=$ & $\begin{array}{l}t_{\text {hitung }}>t_{\text {tabel }} \\
\text { sehingga } \\
\text { Hipotesis } \\
\text { Diterima. }\end{array}$ \\
\hline
\end{tabular}

Berdasarkan Tabel 2,3 dan 4 nilai rata-rata kompetensi keterampilan kelas eksperimen lebih tinggi dibandingkan kelas kontrol. Uji normalitas data pada kedua kelas sampel memiliki L0 < Lt yang berarti bahwa data terdistribusi normal. Uji homegenitas menunjukkan bahwa Fhitung < Ftabel yang berarti bahwa data memiliki varians yang homogen. Dari hasil uji normalitas dan uji homogenitas didapatkan data pada kelas sampel terdistribusi normal dengan varians yang homogen maka dilanjutkan dengan uji $\mathrm{t}$ yang dimana didapatkan hasil thitung >ttabel yang berarti hipotesis diterima.

\section{Kompetensi Pengetahuan}

Berdasarkan hasil uji hipotesis, didapatkan model pembelajaran scramble bermuatan literasi sains berpengaruh terhadap kompetensi pengetahuan peserta didik kelas VIII pada materi sistem pernapasan manusia di SMPN 13 Padang. Hal ini dapat dilihat dari nilai rata-rata posttest dimana kelas eksperimen memiliki nilai rata-rata yang lebih tinggi yaitu 73,25 dibandingkan dengan kelas kontrol yaitu 67,13. Perbedaan nilai rata-rata pada kelas eksperimen yang menggunakan model pembelajaran scramble bermuatan literasi sains dengan kelas kontrol yang menggunakan model pembelajaran konvensional menandakan model pembelajaran mempengaruhi hasil belajar peserta didik.

Kelebihan model pembelajaran scramble bermuatan literasi sains pada penelitian ini yaitu model ini mampu melatih peserta didik berpikir dan memecahkan masalah. Hal ini sesuai dengan hasil penelitian yang dilakukan oleh Artini dkk (2014) dimana model pembelajaran scramble mampu mengembangkan kemampuan peserta didik dalam berpikir, memecahkan masalah, menalar, berkomunikasi baik dalam pembelajaran maupun dalam kehidupan sehari-hari.

Penerapan model pembelajaran scramble bermuatan literasi sains pada kelas eksperimen dibantu dengan media berupa slide power point ketika guru menyampaikan materi. Selama proses penyampaian materi berlangsung guru melakukan tanya jawab menggunakan alat bantu literasi sains yaitu pada pertemuan pertama berupa ADIKSIMBA (apa, dimana, kapan, siapa, mengapa dan bagaimana), pertemuan kedua berupa RANTAI PERISTIWA, pertemuan ketiga berupa SEBAB-AKIBAT dan pada setiap kegiatan akhir selalu menggunakan ADIKSIMBA (apa, dimana, kapan, siapa, mengapa dan bagaimana), sehingga terjadi interaksi antara guru dan peserta didik dan peserta didik menjadi lebih aktif. Aunurrahman (2009:42) mengemukakan proses belajar mengajar dapat terjadi dengan baik ketika peserta didik ikut berpartisipasi secara aktif didalamnya. 
Penggunaan alat bantu literasi sains dapat membantu peserta didik dalam memahami serta mengaitkan satu konsep dengan konsep lainnya dalam kehidupan sehari hari, merumuskan masalah, menganalisis dan mencari solusi terhadap sebuah permasalahan. Hal ini juga dikemukakan oleh Yuliati (2017: 27) yaitu penilaian literasi sains bukan hanya untuk mengukur tingkat pemahaman peserta didik terhadap pengetahuan sains tetapi juga pemahaman peserta didik terhadap aspek proses sains dan kemampuan mengaplikasikan pengetahuan dan proses sains dalam kehidupan nyata peserta didik.

\section{Kompetensi Sikap}

Kompetensi sikap merupakan salah satu faktor yang mempengaruhi hasil belajar peserta didik.Sudijono (2011:54) mengemukakan ciri-ciri hasil belajar efektif akan tampak pada tingkah laku atau sikap peserta didik, seperti perhatiannya terhadap suatu mata pelajaran, kedisiplinannya dalam mengikuti pembelajaran atau motivasinya yang tinggi untuk mengetahui materi pembelajaran dan sebagainya. Novidsa, dkk (2017:91) mengungkapkan dilakukannya penilaian sikap bertujuan untuk melihat dan mengetahui capaian perilaku peserta didik sesuai dengan tuntutan kompetensi dasar dan kompetensi inti sikap spiritual dan sikap sosial.

Berdasarkan hasil analisis data kompetensi sikap didapatkan yaitu rata-rata nilai sikap kelas eksperimen lebih tinggi yaitu 81,31dibandingkan kelas kontrol yaitu 73,28 . Hal ini terbukti bahwa model pembelajaran scramble bermuatan literasi sains berpengaruh meningkatkan kompetensi sikap peserta didik.Peningkatan kompetensi sikap peserta didik juga menandakan meningkatnya minat dan motivasi belajar peserta didik. Hal ini sesuai dengan hasil penelitian yang dilakukan oleh Imami dkk (2018:255) yaitu model pembelajaran scramble mampu meningkatkan minat belajar peserta didik serta hasil belajar secara maksimal.

Kompetensi sikap yang dinilai pada penelitian ini adalah yang pertama sikap disiplin, Diani (2016:272) mengemukakan tahap-tahap kegiatan model pembelajaran scramble ini mampu mendorong pemahaman peserta didik terhadap materi pembelajaran dengan bantuan teman-teman sesama peserta didik dan adanya pembelajaran yang melatih sikap disiplin.Selain sikap disiplin model pembelajaran scramble juga melatih peserta didik menjadi lebih percaya diri, hasil penelitian yang dilakukan Diena dkk (2015:20) bahwa model pembelajaran scramble mampu membuat peserta didik lebih aktif dalam kegiatan diskusi dan lebih berani mengemukakan pendapat. Selain disiplin, nilai sikap jujur, percaya diri dan tanggung jawab peserta didik kelas eksperimen juga tergolong tinggi ini dapat dinilai ketika model scramble diterapkan, dimana masing-masing anggota kelompok memiliki tanggung jawab tersendiri terhadap jawaban dari 10 kartu soal yang diberikan guru. Huda (2013:304) mengemukakan salah satu kelebihan model pembelajaran scramble adalah melatih sikap tanggung jawab peserta didik. Sikap jujur pada kelas eksperimen dapat dilihat ketika satu persatu anggota dari masing masing kelompok harus mencari kartu jawaban didepan sesuai dengan peraturan yang telah di beritahu sebelum pencarian jawaban dimulai sehingga hanya ada 6 orang yang ada didepan yang merupakan perwakilan masing masing kelompok. 


\section{Kompetensi Keterampilan Peserta Didik}

Kompetensi keterampilan atau psikomotor merupakan kompetensi yang menilai kemampuan seseorang dalam melakukan suatu tugas tertentu. Kunandar (2015:255) mengemukakan kompetensi psikomotor merupakan kompetensi yang berkaitan dengan keterampilan (skill) atau kemampuan bertindak setelah seseorang menerima pengalaman belajar tertentu.Penilaian keterampilan pada penelitian ini adalah penilaian produk berupa poster. Penilaian ini dilakukan dengan cara mengamati hasil produk yang telah dibuat oleh peserta didik secara individu.

Penilaian terhadap kompetensi keterampilan ini perlu dilakukan untuk melihat bagaimana cara peserta didik mengaplikasikan ilmu atau teori yang telah mereka pelajari. Hal ini sesuai dengan yang di kemukakan oleh Kunandar (2015:306) yaitu penilaian produk mampu menilai peserta didik dalam mempraktikkan ilmu yang telah diperoleh secara langsung melalui pengalaman nyata serta dapat menilai kreatifitas peserta didik yang berkaitan dengan daya cipta dan kompetensi yang dimiliki oleh peserta didik.

Berdasarkan hasil uji analisis data observasi penilaian kompetensi keterampilan, kelas yang menggunakan model pembelajaran scramble bermuatan literasi sains memiliki rata-rata nilai yang lebih tinggi, ini terlihat bahwa model pembelajaran yang digunakan dikelas eksperimen memiliki pengaruh positif terhadap kompetensi keterampilan peserta didik. Menurut Risdiyanto (2019:122) ketertarikan peserta didik dalam suatu pembelajaran pembelajaran membuat peserta didik lebih semangat untuk menuangkan gagasan atau ide ide kreatifnya kedalam sebuah produk/ karya. Seperti hasil penelitian yang dilakukan oleh Sudarmi dan Burhannudin (2017:78) yaitu model pembelajaran scramble berpengaruh positif dalam meningkatakan keterampilan menulis dan motivasi belajar peserta didik.

\section{KESIMPULAN}

Berdasarkan hasil penelitian yang telah dilaksanakan maka disimpulkan bahwa model pembelajaran Scramble bermuatan literasi sains berpengaruh positif terhadap kompetensi pengetahuan, sikap dan keterampilan peserta didik kelas VIII SMPN 13 Padang.

\section{DAFTAR PUSTAKA}

Artini, A. A. Ayu Sri Vidya. I Wyn, Sujana. dan I Km Ngurah Wiyasa. 2014. Pengaruh Model Pembelajaran Scramble Berbantuan Media Semi Konkret Terhadap Hasil Belajar IPS Siswa Kelas V SD Gugus Kapten Kompiang Sujana. E- Journal PGSD Universitas Pendidikan Ganesha. Jurusan PGSD. Vol 02. No 1.

Aunurrahman. 2009. Belajar dan Pembelajaran. Bandung: Alfabeta.

Diani, R., Yuberti dan S, Syafitri. 2016. Uji Effect Size Model Pembelajaran Scramble Dengan Media Video Terhadap Hasil Belajar Fisika Peserta Didik Kelas X MAN 1 Pesisir Barat. Jurnal Ilmiah Pendidikan Fisika AlBiruni. Vol 05. No 2.

Diena, B, B., Pujiastuti dan Siti,M. 2015. Penerapan Metode Pembelajaran Scrambledan Time Token untuk Meningkatkan Motivasi dan Hasil Belajar Siswa Kelas XI IPA 2 SMA Negeri 3 Jember (Pokok Bahasan Sistem Reproduksi Manusia). Jurnal Edukasi.Vol 02 No 3. 
Huda, M. 2013. Model-model Pengajaran dan Pembelajaran. Yogyakarta: Pustaka Pelajar.

Imami, F., Wasitohadi, Rahayu, T.S. 2018. Peningkatan Minat Belajar Tematik Mupel IPA Melalui Pembelajaran Kooperatif Tipe Scramble Siswa Kelas 5 SDN Salatiga 09 Tahun Pelajaran 2017/2018. Jurnal Pendidikan Berkarakter. Mataram.

Jumania, Irawan Bony, Putri, A.N. 2019. Profil Keterampilan Proses Sains Siswa Dalam Pembelajaran IPA Kelas Viii Di SMP Negeri 8 Tanjungpinang. Pedagogi Hayati Volume 3 No 1. https://doi.org/10.31629/pedag.\%20haya ti.v3i1.1340

Jufri, Wahab. 2013. Belajar dan Pembelajaran Sains. Bandung: Pustaka Reka Cipta

Kunandar. 2015. Penilaian Autentik. Jakarta: Rajagrafindo Persada.

Ngalimun. 2012. Strategi dan Model Pembelajaran. Yogyakarta: Aswaja Pressindo.

Novidsa, I., Syamsurizal, dan R. Darusyamsu. 2017. "Peningkatan Kompetensi Sikap Peserta Didik Dengan Penerapan Strategi Learning Community Melalui Model Pembelajaran Inkuiri Pada Materi Struktur dan Fungsi Jaringan Tumbuhan Kelas VIII di SMPN 12 padang". Bioeducation Journal. Vol01. No 2.

OECD. 2016. Programme For International Student Assessment (PISA) Result From PISA 2015.

Risdiyanto, T. A., E. Yuniarti., R. Yogica., Syamsurizal. 2019. PengaruhModel Pembelajaran Teams Games Tournament (TGT)Bermuatan Literasi Sains terhadap Kompetensi Belajar Peserta Didik pada Materi Sistem Pernapasan Manusia.Atrium Pendidikan Biologi. Volume 4 No 1.

Sudarmi dan Burhanuddin. 2017. Keefektifan Model Pembelajaran Kooperatif Tipe Scramble dalam Keterampilan Menulis Kalimat Bahasa Jerman Siswa Kelas XI SMA Negeri 11 Makassar.Eralingua :
Jurnal Pendidikan Bahasa Asing dan Sastra. Volume 1 No 1.

Sudijono, Anas. 2011. Pengantar Evaluasi Pendidikan. Jakarta: Rajawali Pers.

Taniredja, T., Faridli, E.M., Harmianto, S. 2012. Model-Model Pembelajaran Inovatif dan Efektif. Bandung: Alfabeta.

Yuliati, Y. 2017. Literasi Sains Dalam Pembelajaran IPA. Jurnal Cakrawala Pendas.Vol 3. No 2. 